DOI 10.37882/2223-2982.2020.04-2.13

\title{
НЕКОТОРЫЕ ПРОБЛЕМЫ ИСПОЛЬЗОВАНИЯ КУЛЬТУРНО-ИСТОРИЧЕСКОГО НАСЛЕДИЯ В ПРОСВЕТИТЕЛЬСКОЙ ДЕЯТЕЛЬНОСТИ
}

\section{SOME PROBLEMS OF USING CULTURAL AND HISTORICAL HERITAGE IN EDUCATIONAL ACTIVITIES}

\author{
V. Grebenyukov \\ T. Shulyak
}

Summary: It is impossible to address any topic without taking into account the opinions of leading figures and experts who form policy in this area. This is why the article refers to the events that have defined the industry's strategy for many years. The most important event was the «Round table» of the Federation Council in 2004. The premise of this article was the idea expressed by M. L. Dementieva about the need for broad educational activities in the field of preserving historical and cultural heritage. Any education is related to the selection of information. The selection of reliable information is impossible if the problem of publication coverage of materials obtained both as a result of archaeological excavations and explorations is not solved. Only a fleeting analysis of the state of Affairs in this area shows deplorable results.

Meanwhile, the comprehensive publication of materials in the form of a report will not only provide an opportunity for broad discussions of professionals, but also allow everyone to adequately assess their abilities to work in a complex field of knowledge. Such publications will also be invaluable for teachers of history, local history, and Museum workers.

Keywords: cultural and historical heritage, educational activities. Archaeological monuments, Nizhnevartovsky district, KhantyMansi Autonomous District - Ugra, publication lighting, profession «archeologist».

\author{
Гребенюков Владимир Иванович \\ к.и.н., профессор, ФГБОУВО «Нижневартовский \\ государственный университет» \\ grebenukov@mail.ru \\ Шуляк Тимур Ильгамович \\ ФГБОУ ВО «Нижневартовский государственный \\ университет» \\ kopaka_nyva@mail.ru
}

Аннотация: Обращение к любой теме невозможно без учета мнения ведущих деятелей и специалистов, формирующих политику в данной области. Именно этим обусловлено обращение в статье к событиям, определивших стратегию отрасли на многие годы. Важнейшим событием стал «Круглый стол» Совета Федерации 2004 года. Посылом к настоящей статье стала мысль, высказанная Дементьевой М.Л., о необходимости широкой просветительской деятельности в области сохранения историко-культурного наследия. Любое просвещение связано с отбором информации. Отбор достоверной информации невозможен, если не решить проблему публикационного освещения материалов полученных как в результате археологических раскопок, так и разведок. Всего лишь мимолетный анализ состояния дел в этой области демонстрирует плачевные результаты.

Между тем, исчерпывающая публикация материалов в форме отчета даст возможность не только для широких дискуссий профессионалов, но и позволит всем желающим адекватно оценить свои способности для работы в сложной отрасли знания. Неоценимыми такие публикации будут и для учителей истории, краеведения, музейных работников.

Ключевые слова: культурно-историческое наследие, просветительская деятельность. археологические памятники, Нижневартовский район, ХантыМансийский автономный округ - Югра, публикационная освещенность, профессия «археолог».

ими движет интерес к прошлому [22, с. 67-73]. Усложняет этот факт ситуацию с охраной культурно-исторического наследия или упрощает, вопрос спорный и практически не изученный. Интерес зачастую является первым шагом к профессии, в данном случае к профессии археолога' ${ }^{1}$. Вплоть до недавнего времени такой профессии не существовало. В массовом сознании, археология присутствовала как некая романтика, доступная лишь «избранным» чудакам. Требования к профессиональной квалификации (высшее историческое образование), отсутствие возможности реализации своего интереса на ином профессиональном уровне формировало специфический

Постановление Госстандарта РФ от 26.12.1994 N 367 (ред. от 19.06.2012) <О принятии и введении в действие Общероссийского классификатора профессий рабочих, должностей служащих и тарифных разрядов ОК 016-94> (вместе с «ОК 016-94. Общероссийский классификатор профессий рабочих, должностей служащих и тарифных разрядов») (дата введения 01.01.1996). 
ореол вокруг профессии.

Невзирая на изменившиеся условия, радения части профессионалов [35, с. 89-93] знаковых деятелей науки (Лихачев, Д.С. Письмо сорок первое ПАМЯТь КУЛьТУРЫ) и общественников не позволяли затушевать новые проблемы в деле сохранения культурно-исторического наследия. Сохранялась и развивалась государственная система охраны историко-культурного наследия. В непростых условиях конца девяностых, была в основном сформирована федеральная база объектов исторического наследия. Примером может служить Постановление Губернатора Ханты-Мансийского автономного округа «О постановке на государственный учёт и охрану как памятников истории и культуры окружного значения вновь выявленных объектов историко-культурного наследия Ханты-Мансийского автономного округа» № 89 от 04.03.1997 г. касавшееся почти тысячи памятников археологии, Для сравнения можно упомянуть Постановление Совета Министров РСФСР «О дальнейшем улучшении дела охраны памятников культуры в РСФСР» № 1327 от 30.08.1960 г. в приложении к которому на охрану был поставлен один памятник археологии на территории Округа стоянка «Чес-Тый-яг» и городище.

Новый импульс делу сохранения дал Федеральный Закон «Об объектах культурного наследия (памятниках истории и культуры) народов Российской Федерации» от 25.06.2002 г. Общественные обсуждения по итогам его реализации проявили обеспокоенность профессионалов и администраторов по большому кругу вопросов [23, с.120-132].

Наиболее значимым событием стал «Круглый стол» Совета Федерации прошедший 19 марта 2004 года. В соответствие со статусом события, обсуждались фундаментальные вопросы сохранения культурно-исторического наследия [17, с.42-44]. Директор Эрмитажа Пиотровский М.Б сделал акцент на экспертизе и учете памятников [37, с.9]. Академик Деревянко А.П. поставил вопрос о совершенствовании законодательной базы в части перемещения предметов культурно-исторического наследия [18, с.10-12]. Макаров Н.А., директор Института археологии Российской академии наук обратил внимание на проблему грабительских раскопок [30, с.13-24]. Вызвала обеспокоенность и практика чрезмерного числа выданных Открытых листов на проведение археологических раскопок [49, с.24-26]. Вместе с реалистичными высказывались соображения, по сути, здравые, но их реализация дело не просто хлопотное, но практически не реализуемое [31, с.38-39]. Наука, преподавание и управление, понятия редко совместимые в современных условиях. Много материалов «круглого стола» было посвящено совершенствованию законодательной базы, с учетом накопленной правоприменительной практики [15, с.61-65; 28, c.44-48,].
С учетом внедрения в практику планирования системы проектов, у отдельных исследователей стала популярна идея разработки и принятия долгосрочных государственных программ, направленных на реализацию конкретных проектов с учетом современных реалий социально-экономического развития регионов [1, с.86].

Начальник отдела охранных раскопок ИА РАН Энговатов А.В. провела колоссальную статистическую работу по числу грабительских раскопок, по доле археологических работ проводимых негосударственными организациями и др. Была приведена информация о публикационном освещении археологических исследований в некоторых странах Европы, а аналогичная ситуация в нашей стране видимо так плачевна, что не нашлось слов и автор ограничилась определением «ничтожно мал». Было высказано и пожелание публикации отчетов в электронном виде с оговоркой «полностью исследованных раскопками [65, с.45].

Подобный подход, в основе которого лежит нежелание давать информацию «черным копателям», можно расценивать по-разному. С одной стороны, яркие находки могут привлечь специфических «любителей старины». С другой стороны, авторы случайных открытий, порой из добрых побуждений несут в местные краеведческие музеи все «что блестит». Понятно, что их не интересует контекст, они о нем ничего не знают. По открытому «адресу» выезжают специалисты, добирают то, что осталось, как то публикуют, используют в обобщающих публикациях, выставляют на сайт «зрелище».

Однако обратимся к конкретным фактам региона проживания авторов к тому же не перенасыщенного археологическими исследованиями.

Комплекс Агрнъёган 1 был случайно открыт в 2003 г. местными жителями. Он находится в среднем течении р. Аган в окрестностях города Радужный в Нижневартовском районе Ханты-Мансийского автономного округа-Югры. Памятник был сильно разрушен. В 2003 г. эколого-этнографический музей г. Радужный приобрел коллекцию, включавшую 120 изделий из бронзы и железа - украшения и предметы вооружения. В 2004 г. совместно с музеем и администрацией города была организована экспедиция под руководством Карачарова К.Г. В результате работ при его изучении извлечено еще 115 предметов и фрагментов. Найденные останки как минимум четырёх людей и фаунистические остатки двух особей северного оленя позволило интерпретировать памятник как могильник. Небольшая заметка с фотографиями отдельных предметов и частичная публикация фотографий в научно-популярном труде исчерпывают наше представление о комплексе [25, с.82-110; 26, с.179184; 36, с.48-87; 64, с.137-141]. В дальнейшем о материалах упоминалось в некоторых обобщающих статьях [2, 
с.217-261; 3, с.41] и интернет-заметках 2 . Спустя пятнадцать лет зрелищные и редкие материалы не введены в научный оборот. Можно апеллировать к собственнику - музею города Радужный. Но музей не частная структура, он часть экспозиционного пространства музейного сообщества субъекта Российской Федерации, финансируемого из государственного бюджета [не важно какого уровня], а функции по охране и надзору памятников [в нашем случае археологии] возложены на службу государственной охраны объектов культурного наследия. Очевидно, у специалистов были основания требовать исчерпывающей публикации материалов. Но сегодня мы не владеем информацией касающейся металлургической базы использованной для изготовления изделий. Применительно к региону, где отсутствует собственная сырьевая база цветных металлов, состав бронз может дать дополнительные и разноплановые сведения. Детальное исследование железных изделий так же было бы не лишним. Не хотелось бы для этих находок судьбы известных утраченных для науки и будущих поколений находок и комплексов [14, с.58-59].

На территории Нижневартовского района на сегодняшний день зарегистрировано около 500-т памятников археологии различных эпох 3 . В соответствие с Федеральным Законом №73-Ф3 «Об объектах культурного наследия [памятниках истории и культуры] народов Российской Федерации» от 25.06.2002 г. все выявленные памятники археологии находятся под охраной в статусе федеральных. Столь высокий уровень охраны связан с особой значимостью археологических объектов культурного наследия. Большая часть человеческой истории может быть изучена исключительно на археологических материалах. Эта аксиома и легла в основу логики современного законодательства. Методы археологических исследований постоянно совершенствуются. Каких то сто лет назад никто и знать не мог о радиоактивных методах датирования, а дендрохронология казалась вершиной естественно-научных методов датирования. Расширяется спектр использования естественнонаучных данных в интересах археологической науки. Постоянно возрастают требования к оформлению отчетной документации по итогам полевых исследований․

Первые археологические исследования на территории Нижневартовского района связаны с именем
Посредникова В.А. ${ }^{5}$ В 1969 году им были открыты и исследованы Большеларьякское поселение II, грунтовые могильники Ларьякский I-II, поселение Корлики, поселения Чехломеевские I-III [31, с.207-208; 38, Посредников 1969: с.76; 40, с.261; 42, с.233; 45, с.217]. Экспедиция под руководством Посредникова В.А. работала на территории Нижневартовского района до 1975 года. Помимо сбора подъемного материала, шурфов и небольших раскопов, Посредников В.А. проводил археологические раскопки на Большеларъякском городище и поселениях Большой Ларьяк II и III [21, с.116-131]. Результаты археологических разведок и раскопок были отражены в одинадцати публикациях, шесть из которых информационного характера [38, с.76; 39. с.207-208; 40, с.261; 42, Посредников 1973: с.233; 45, с.217; 46, с.227228]. Одна заметка была посвящена обзору материалов Большеларьякского городища [48, с.299-306] и четыре статьи обобщающие [41, с.32-33; 43, с.95-107; 37, с.3-28; 44, с.217-220]. Тем не менее, на такую далеко не полную информацию в дальнейшем ссылался целый ряд исследователей [10, с.13-14; 11, с.31-33; 4, с.41; 9, с.3-14; 62, с.48; 33, Мызников, Косинская, Стефанов 2012: с.69; 6, с.3-13; 24, с.146]. Посредникова В.А. сменил Васильев Е.А. проводивший в 1976 году первые археологические исследования в бассейне р. Аган. Им были обследованы территории в верхнем течении р. Аган от озера Мэнсавэмтор до посёлка Новоаганск. Возможно, переориентация на исследования в Советском и Березовском районах Ханты-Мансийского автономного округа [5, с.213; 7, с.212; 8 , с.194] отвлекли исследователя и не позволили подвести итоги своих изысканий в Нижневартовском районе. Прорисовки фрагментов отдельных сосудов поселений Большой Ларьяк II, Большой Ларьяк III, Чехломеевского поселения не могли заменить полноценную публикацию материалов раскопок [6, с.3-13, рис. 1,2.]. Не забывал Васильев Е.А. Югорскую археологию и в нулевые двадцать первого столетия [12, с.296-301; 13, с.514-518], но к полученным ранее материалам так и не вернулся.

Исследования проводившиеся на территории Нижневартовского района в период с 1975 по 1980 год не нашли своего отражения даже в ежегоднике «Археологические открытия». И только труды Стефановой Н.К., Борзунова В.А. [62, с.105] и Зайцевой Е.А. [21, с.121] позволяют увидеть хронику исследований перечислить фамилии тех, кто вел исследования, но не опубликовал

2 О०О НПО «Северная археология 1». http://археологиясевера.рф/

3 Информация о деятельности Службы государственной охраны объектов культурного наследия Ханты-Мансийского автономного округа - Югры в 2016 г. [с.4-32] Ханты-Мансийский автономный округ в зеркале прошлого: Сб. статей / Отв. ред. К.Г. Карачаров и Я.А. Яковлев. - Томск; Ханты-Мансийск; Изд-во Том. ун-та, 2017. Вып. 15. 512 с.

4 ПОЛОЖЕНИЕ о порядке проведения археологических полевых работ и составления научной отчётной документации. УТВЕРЖДЕНО постановлением Бюро Отделения историко-филологических наук Российской академии наук от «20» июня 2018 г. № 32. http://www.archaeolog.ru/media/2018/Polozhenie_2018_2.pdf Проверено 02.02.2020 г.

5 Сотрудник проблемной научно-исследовательской лаборатории истории, археологии, этнографии Сибири Томского государственного университета. 
их итоги. Васильев Е.А., Смирнов Н.Г., Байдин В.И.

Остались в основном не опубликованными материалы археологических экспедиций Семёновой В.И., научного сотрудника Тюменского областного краеведческого музея. Изученные ею раскопками поселение и городище в районе поселка Урьево удостоились информации в сборнике «Археологические открытия» за 1980 и 1981 гг. [50, с.208-209; 51, с.230]. Такая же судьба постигла и материалы городища Лангепас 1 [58, с.256-257]. Недостаток публикаций можно было списать на общую ситуацию с возможностями публикации материалов в Советский период, но в 90-е годы открылись широкие возможности для публикаций и исследователь достаточно активно пользовалась ими [52, с.189-191; 54, с.6484 ; 55, с.140-159 ; 53, с. 178-180; 56, с.78-79; 57, 296с. и др.]. Нам остается лишь догадываться, какие материалы были получены при раскопках 3-х жилищ на городище Урьевское I и одного жилища на Урьевском III и верить «на слово» предложенным датировкам [50, с.208-209].

В 1992 году к исследованиям в Нижневартовском районе присоединилась экспедиция Тобольского педагогического института работала. По заданию Мегионского историко-этнографического музея проводилось сплошное обследование бассейна р. Аган. Были проведены раскопки на городищах Старые Покачи I, Старые Покачи III, Старые Покачи IV и поселениях Варъеган VI, Аган III По этим раскопкам нет ни одной публикации [62, c.105].

Больше всего «повезло» остаткам речного деревянного судна (барки) 1-й трети XIX в., обнаруженные в 1997 г. местным жителем на берегу протоки Кирьяс (левобережье реки Обь) [19, с.95-107; 27, с.56-62; 59, с.317-328]. В 1998 Нижневартовском районе группа под руководством В. М. Морозова исследовала этот объект [20, с.156159]. Практически исчерпывающая публикация полевых материалов изучения судна редкий случай для археологии региона.

Одним из основных учреждений занимающимся археологическими исследованиями в Нижневартовском районе можно назвать ООО «НПО "Северная археология"». За 20 лет коллектив ООО «НПО “Северная археология"» реализовал на территории района комплекс охранных работ. За 20 лет произведены противоаварийные раскопки на 30 памятниках археологии: городища Старые Покачи 5, Мохтикъеган 5, селища Коттымъеган 1, 2, 3, 4, 5, 6, 9, Нёх-Урий 3, 3.2, 5, 5.1, 6.1, Мохтикъёган 4, 8, $15,16,17,19,22$; могльники Нёх-Урий 3.5, Мохтикёган 23, ловчие ямы Нонкъёган 6, 7, Старый Аган 5 и другие. Об- щая площадь раскопов около 27000 кв. м. ${ }^{6}$ К сожалению, лишь небольшая часть материалов полученных в ходе археологических раскопок удостоилась серьезного публикационного освещения. Из доступного к ознакомлению материала часть была опубликована в соавторстве со специалистами из Екатеринбурга, либо исключительно последними $[16$, с. 259-275; 32, с. 459-462; 31, с.146$169 ; 59$, с.84-96; 60, с.48-84].

Где брать материалы для серьезной просветительской работы, о которой говорила Н.Л. Деметьева (с сентября 1998 по апрель 2004 года - первый заместитель министра культуры РФ) [Дементьева 2004: 42-44] видимо так и будет риторическим вопросом. При таком положении дел мы вновь и вновь вынуждены повторять, что культурное наследие не интегрировано в современную жизнь общества [1, Бахшиев 2015: с.77-88]. Если, по мнению Наполеона 1 Бонапарта «История - это лишь версия случившихся событий в нашей интерпретации», то памятники археологии неоспоримый факт. Другой вопрос, как этот факт получен и насколько скрупулезно зафиксированы события культурного слоя, где артефакты весомая, но лишь малая часть этого факта. Что популяризировать и как просвещать - самая большая проблема, решение которой не имеет простого решения. Любое просвещение связано с отбором информации. Можно придумать информацию, что успешно делается отдельными «популяризаторами». Можно опереться на зрелищность отдельных артефактов или их комплексы. Можно музеефицировать комплексы и ансамбли. По нашему мнению, все это мало будет содействовать популяризации региональных древностей и не решит проблему публикационного освещения материалов полученных как в результате археологических раскопок, так и разведок.

Исчерпывающая публикация материалов в форме отчета даст возможность не только для широких дискуссий профессионалов, но и позволит всем желающим адекватно оценить свои способности для работы в сложной отрасли знания. Неоценимыми такие публикации будут и для учителей истории, краеведения, музейных работников.

Не менее важен такой подход и для популяризации знаний о прошлом в визуальной форме, ибо позволит привлечь художников, специалистов декоративно-прикладного профиля для использования материалов древности в качестве сюжетов для своего творчества.

Электронная публикация отчетов позволит музеям динамично обновлять и расширять виртуальные экспо-

6 Информация на сайте $О О О$ «НПО “Северная археология”»: http://археологиясевера.рф/страница-два-тест/археология-севера/ исследования-в-западно-сибирской-тай/ Проверено 02.02.2020 г. 
зиции древностей региона. Отсутствие в штатах музеев профессиональных археологов может быть компенсировано передачей подобной работы на аутсорсинг, а растущие возможности удаленной работы позволяет выполнять такой заказ специалистами из любого региона.

Такая работа не требует серьезных финансовых затрат, археологи предоставляют отчеты в институт архе- ологии РАН в электронном виде. Остается сделать их доступными для всех желающих.

Публичность итогов археологических исследований сделала археологию общественно значимым видом деятельности. Более того, Конституция нашей страны гарантирует гражданам право на доступ к культурным ценностям (реализация ст. 44 Конституции РФ п. 2) ${ }^{7}$.

\section{ЛИТЕРАТУРА}

1. Бахшиев И.И. 2015. Сохранение объектов археологического наследия в Республике Башкортостан на современном этапе (особенности государственного регулирования и узловые проблемы). Сохранение археологического наследия: проблемы и перспективы. Материалы конференции «Противодействие незаконной деятельности в области археологии». Москва, 9-10 декабря 2013 г. - М.: ИА РАН, 2015. с.77-88.

2. Борзунов В.А, Чемякин Ю.П. 2012. Карымское общество таёжного Приобья: некоторые аспекты его генезиса, развития и взаимодействия с соседями. // Ханты-Мансийский автономный округ в зеркале прошлого: Сб. статей / Отв. ред. Я.А. Яковлев. - Томск; Ханты-Мансийск: Изд-во Том. ун-та, 2012. Вып. 10. c.217-261.

3. Борзунов В.А.,Че мякин Ю.П. 2012. Карымские памятники таёжного Приобья: основные характеристики. // Ханты-Мансийский автономный округ в зеркале прошлого: Сб. статей / Отв. ред. Я.А. Яковлев. - Томск; Ханты-Мансийск: Изд-во Том. ун-та, 2012. Вып. 10. С. 155-216.

4. Борзунов В.А., Чемякин Ю.П. 2013. Карымские памятники таёжного Приобья: История изучения, хронология и территория распространения. Вестник археологии, антропологии и этнографии. 2013. № 1 (20) с.34-46.

5. Васильев Е.А. 1978. Работы в Нижнем Приобье. Археологические открытия 1977 года. // М.: Наука, 1978. с. 213.

6. Васильев Е.А. 1978. Гребенчато-ямочная керамика Среднего Приобья. Этнокультурная история населения Западной Сибири. - Томск: Изд-во Том. ун-та, 1978. C. 3-13.

7. Васильев Е.А. 1979. Исследования памятников эпохи бронзы в таёжном Приобье. Археологические открытия 1978 года. // М.: Наука, 1979. с.212;

8. Васильев Е.А. 1980. Работы в Нижнем Приобье. Археологические открытия 1979 года. // М.: Наука, 1980. с.194.

9. Васильев Е.А. 1982. Северотаежное Приобье в эпоху поздней бронзы // Археология и этнография Приобья. — Томск: Изд-во Том.ун-та, $1982 .-$ С.3 - 14.

10. Васильев Е.А. 1987. Миграционные процессы в таежной полосе Западной Сибири в энеолитическую эпоху (причина и динамика) // Смены культур и миграции в Западной Сибири. Томск: Изд-во ТГУ, 1987. С. 13-14.

11. Васильев Е.А. 1991. К проблеме среднеазиатско-западносибирских связей в неолитическую эпоху // Проблемы хронологии и периодизации археологических памятников Южной Сибири: Тез. докл. Барнаул, 1991. С. 31-33.

12. Васильев Е.А. 2004. Раскопки неолитического поселения Чэс-Тый-Яг на Приполярном Урале. // Ханты-Мансийский автономный округ в зеркале прошлого: Сб. статей / Отв. ред. Я.А. Яковлев. - Томск: Изд-во Том. ун-та, 2004. Вып. 2. с.296-301.

13. Васильев Е.А. 2010. Древности Конды: Субъективные заметки (Кокшаров С.Ф. Памятники энеолита севера Западной Сибири. - Екатеринбург: Изд-во НПМП «Волот», 2009). // Ханты-Мансийский автономный округ в зеркале прошлого: Сб. статей / Отв. ред. Я.А. Яковлев. - Томск; Ханты-Мансийск: Изд-во Том. ун-та, 2010. Вып. 8. с.514-518.

14. Вдовин А.С., Н.П. Макаров. 2011. Утраченные археологические коллекции Красноярского музея. Второй век подвижничества. // Красноярск: КККМ. 2011, c.58-59.

15. Гетманский С.А. 2004. Вопросы сохранения археологического наследия Российской Федерации. «Круглый стол» Совета Федерации «Сохранение археологического наследия России» 19 марта 2004 года. Издание СФ. 91 с, с. 61-65.

16. Данилова, Е.Н., Бахарев П.С. 2016. Река Аган на заре железного века. // Ханты-Мансийский автономный округ в зеркале прошлого: Вып. 14 Томск; Ханты-Мансийск, 2016 Вып. 14. С. 259-275.

17. Дементьева Н.Л. 2004.0 деятельности Министерства культуры и массовых коммуникаций по сохранению культурного наследия. «Круглый стол» Совета Федерации «Сохранение археологического наследия России» 19 марта 2004 года. Издание СФ с.42-44.

18. Деревянко А.П. 2004. Археологическое наследие России: Проблемы сохранения и исследования. «Круглый стол» Совета Федерации «Сохранение археологического наследия России» 19 марта 2004 года. Издание СФ с.10-12.

19. Дубровин Г.Е. 2003. Обское судоходство XVI-ХIX вв. и судно с притоки Кирьяс / Г.Е. Дубровин, В. М. Морозов // Проблемы истории России. Екатеринбург: Волот, 2003. Вып. 5: На перекрестках эпох и традиций. С. 95-107.

20. Дубровин Г.Е., Морозов В.М., Гасникова Н.А. 2000. Судно с протоки Кирьяс и обское судоходство (XVI-XIX вв.) // Русские старожилы: Материалы III Сиб. симп. «Культ. наследие народов Зап. Сибири» (Тобольск, 11-13 дек. 2000 г.). Тобольск, 2000, с. 156-159.

7 Конституция Российской Федерации» (принята всенародным голосованием 12.12.1993) (с учетом поправок, внесенных Законами РФ о поправках к Конституции РФ от 30.12.2008 N 6-ФК3, от 30.12l2008 N 7-ФК3, от 05.02.2014 N 2-ФК3, от 21.07.2014 N 11-ФК3). 
21. Зайцева Е.А. 2012. История археологических исследований Сургутского Приобья (конец XIX - 90-е годы XX вв.). Вестник угроведения №1(8), 2012. с.116131.

22. Зеленцова 0.В. 2010. Сохранение археологического наследия и проблема грабительских раскопок. Тамбовские древности. Археология Окско-Донской равнины, археологический сборник. Тамбовский государственный университет им. Г.Р. Державина; ответственный редактор: С.И. Андреев. Тамбов, 2010. Издательство: С. 67-73.

23. Казанцева 0.А. 2015. Популяризация археологического наследия как форма предупреждения незаконных раскопок. Сохранение археологического наследия: проблемы и перспективы. Материалы конференции «Противодействие незаконной деятельности в области археологии». Москва, 9-10 декабря 2013 г. - М.: ИА РАH, 2015. 192 c.

24. Карачаров К.Г. 2006. Вожпайская археологическая культура // Уральский исторический вестн. Екатеринбург: Ур0 РАН, 2006. №14. С. 135-149.

25. Карачаров К.Г. 2011. Комплекс предметов раннего железного века, найденный у городища Нивагальское 20 на р. Агане // Ханты-Мансийский автономный округ в зеркале прошлого. - Томск; Ханты-Мансийск: Изд-во Том. ун-та, 2011. - Вып. 9. - С. 82-110.

26. Карачаров К.Г., Носкова Л.В. 2006. Исследования в Нижневартовском и Сургутском районах Ханты-Мансийского автономного округа // Ханты-Мансийский автономный округ в зеркале прошлого. - Томск; Ханты-Мансийск: Изд-во Том. ун-та, 2006. - Вып. 3. - С. 179-184.

27. Копейкин М.Л., Кухтерин С.А. 2015. Кирьясская барка. Опыт раскопок, извлечения и транспортировки. Вопросы подводной археологии. 2015. № 06. С. $56-62$.

28. Левина Н.В. 2004. Совершенствование законодательного обеспечения в области сохранения археологического наследия народов Российской Федерации [практика применения действующего законодательства на территории Тверской области]. «Круглый стол» Совета Федерации «Сохранение археологического наследия России» 19 марта 2004 года. Издание СФ, с. 44-48.

29. Лихачев, Д.С. Письма о добром и прекрасном / Д.С.Лихачёв. - М., 1989. - С. Письмо сорок первое «Память культуры»; URL: https://mirkultura.ru/pisma-0dobrom-i-prekrasnom-pismo-40-41-0-pamyati-d-s-lihachyov/ (07.02.2018).

30. Макаров Н.А. 2004. Грабительские раскопки как фактор уничтожения археологического наследия России. «Круглый стол» Совета Федерации «Сохранение археологического наследия России» 19 марта 2004 года. Издание СФ, с.13-24.

31. Медведев Г.И. 2004. Состояние ископаемых культурных запасов Байкальской Сибири и меры, необходимые для их сохранения и изучения. . . «Круглый стол» Совета Федерации «Сохранение археологического наследия России» 19 марта 2004 года. Издание СФ, с.38-39.

32. Мызников С.А. Селище Савкинская речка 1 - памятник эпохи бронзы в низовьях р. Вах // Ханты-Мансийский автономный округ в зеркале прошлого. Ханты-Мансийск; Томск, 2011. Вып. 9. С. 459-462.

33. Мызников, С.А., Косинская Л.Л., Стефанов В.И. 2012. Селище Савкинская Речка 1: новые материалы по бронзовому веку среднетаежного Приобья // Вестник археологии, антропологии и этнографии. 2012. № 3. с. 60-72.

34. Носкова Л.В., Карачаров К.Г. Энеолитический могильник Старые Покачи 5.1 на реке Аган // Барсова Гора. Екатеринбург; Сургут: Урал. изд-во, 2008. с. $146-169$.

35. Обыденнов М.Ф., Яминов А.Ф. 1996. Развитие законодательства об обеспечении сохранения культурного наследия / М.Ф.0быденнов, А.Ф.Яминов // Система законодательства Республики Башкортостан: становление и дальнейшее развитие: Материалы республиканской научно-практической коференции, 27 февраля 1996, г.Уфа / Отв. ред. Ф.М.Раянов. Уфа, 1996, с. 89-93.

36. Перевалова Е.В., Карачаров К.Г. 2006. Река Аган и её обитатели. - Екатеринбург; Нижневартовск: Изд-во Ур0 РАН; Студия «Графо», 2006.352 с.

37. Пиотровский М.Б. 2004. 0 проблемах сохранения культурного наследия «Круглый стол» Совета Федерации «Сохранение археологического наследия России» 19 марта 2004 года. Издание ФФ, с.8-9.

38. Посредников В.А. 1969. Археологические работы на р. Вах. Из истории Сибири. Выпуск второй. Полевые работы 1969 года. // Томск: ТГУ. 1969 , с.76.

39. Посредников В.А., Кирюшин Ю.Ф. 1970. Разведка на реках Вах и Васюган. // АО 1969. М.: Наука, 1970, с. $207-208$.

40. Посредников В.А., 1972. Раскопки неолитического поселения на р. Вах. АО 1971 года. // М.: Наука, 1972, с.261.

41. Посредников В.А. 1972. Культурно-генетическое место комплексов Самусь-IV и некоторых других памятников Приобья // СА. 1972. № 4. С. $28-41$.

42. Посредников В.А. 1973. Работы на р. Вах. АО 1972 года. // М.: Наука, 1973, с. 233.

43. Посредников В.А. 19736. 0 культурно-этнической принадлежности поселения Большой Ларьяк II и некоторых других памятников в таежном Приобье (эпоха бронзы). Из истории Сибири. Выл. 7. Томск, 1973, с. 95-107.

44. Посредников В.А. 1973в. К вопросу об основных этапах истории Среднего и Верхнего Приобья в эпоху бронзы // Происхождение аборигенов Сибири и их языков. Томск: Изд-во ТГУ, 1973, с. 217-220.

45. Посредников В.А. 1974. Исследования в Сургутском Приобье. АО 1973 года.// М.: Наука, 1974, с.217.

46. Посредников В.А. 1975а, Работы в Сургутском Приобье.// АО 1974 года. М.: Наука, 1975, с. 227-228.

47. Посредников В.А. 19756, Хозяйство еловского населения Приобья // Из истории Сибири. Томск, 1975. Вып. 16, с. 3-28.

48. Посредников В. А., 1981. Большеларьякское городище // СА. 1981, № 2. М.: Наука, С. 299-306.

49. Седов В.В. 2004. Полевые археологические исследования в России: Проблемы научной и правовой документации. «Круглый стол» Совета Федерации «Сохранение археологического наследия России» 19 марта 2004 года. Издание СФ, с.24-26.

50. Семёнова В.И. 1981. Раскопки Урьевских городищ. // АО 1980 года. М.: Наука, 1981, с. 208-209.

51. Семёнова В.И. 1983. Исследования в окрестностях пос. Урьево. // АО 1981 г. М.: Наука, 1983, с.230.

52. Семенова В.И., 1992. Хронология погребений могильника Усть-Балык // Археологические культуры и культурно-исторические общности Большого Урала. Тез. докл. Екатеринбург: ИИА Ур0 РАН, УрГУ, с. 189-191.

53. Семенова В.И., 1993. Русские вещи из раскопок хантыйского городка Мункысь Урий к. XVI - н. XVII вв. // Культурно-генетические процессы в Западной 
Сибири. Тез. докл. Томск: ТГУ, с.178-180.

54. Семенова В.И. 1995. Предметы вооружения из погребений могильника Усть-Балык (конец I—I тыс. н.э.) // Древняя и современная культура Западной Сибири. - Тюмень, 1995, с.64- 84.

55. Семенова В.И. 1997. Итоги работы Северного отряда археологической экспедиции объединения ТОКМ (1983—93) // Ежегодник ТОКМ. — Тюмень, 1997, c. $140-159$

56. Семенова В.И., 1999. Оппозиции «мужской - женский», «левый - правый» по материалам Киняминских могильников // Обские угры. Тобольск - 0мск: ОмГПУ, с. 78-79.

57. Семенова В.И., 2001. Средневековые могильники Юганского Приобья. Новосибирск: Наука, 296 с.

58. Семёнова В.И., 2002. Раскопки городища Лангепас І в Нижневартовском районе. // Ханты-Мансийский автономный округ в зеркале прошлого: Сб. статей / Отв. ред. Я.А. Яковлев. - Томск; Ханты-Мансийск, 2002. -Вып. 1, с. 256-257.

59. Скоробогатова А.Ю., Пушкарёв А.А., Кухтерин С.А., Копейкин М.Л. 2016. Работы по изучению и сохранению выявленного объекта археологического наследия «Кирьясская барка» в Нижневартовском районе ХМАО-Югры. // Ханты-Мансийский автономный округ в зеркале прошлого: Сб. статей / Отв. ред. Я.А. Яковлев. - Томск; Ханты-Мансийск, 2016. - Вып. 14. 452 с. Последние полевые сезоны: 2014-2015 гг с.317-328.

60. Стефанов В.И., Данилова Е.Н. Кульёганские древности среднего Агана // Ханты-Мансийский автономный округ в зеркале прошлого. - Томск; ХантыМансийск: Изд-во Том. ун-та, 2013. - Вып. 11, с.84-96.

61. Стефанов В.И., Косинская Л.Л., Карачарова Л.В. Энеолитический комплекс селища Нёх-Урий 3.2 в бассейне р. Аган. // Ханты-Мансийский автономный округ в зеркале прошлого. Вып. 12: (сборник статей) Томск; Ханты-Мансийск, 2014 Вып. 12, с.48-84.

62. Стефанова Н.К., Борзунов В.А. 2002. Археология таежного 0бь-Иртышья. (Хроника полевых исследований на территории Ханты-Мансийского автономного округа) Екатеринбург. 2002, 146 с.

63. Чемякин Ю.П. 2013а. Антропоморфные глиняные фигурки белоярской культуры. Вестник Пермского университета. Выпуск 1 (21) 2013 , с.48-52.

64. Чемякин Ю.П. 20136. Культовая металлопластика сургутского варианта Кулайской культуры. Вестник Томского государственного университета. История. 2013. №2 (22), c.137-141.

65. Энговатова А.В. 2013. Сохранение археологического наследия в России: современное состояние // Вестник Новосибирского государственного университета. Серия История, филология. 2013. Т. 12. № 3, с. 32-47.

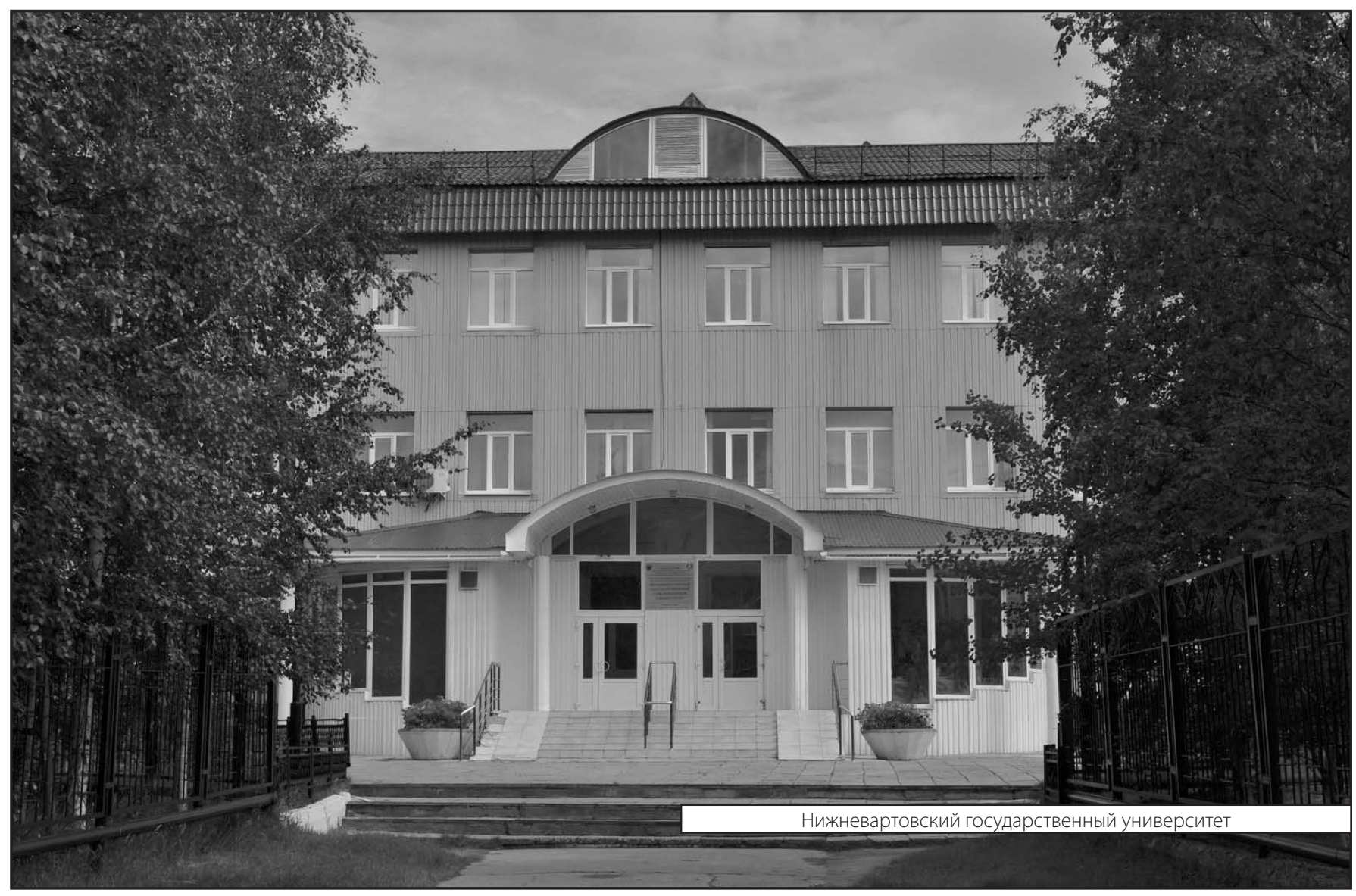

